\title{
A THEORETICAL REVIEW OF CRM EFFECTS ON CUSTOMER SATISFACTION AND LOYALTY
}

\author{
Kamrul Islam Shaon, S. M., Rahman, H.
}

\begin{abstract}
This paper has been devoted to theoretically examining the Customer Relationship Management (CRM) agenda which has been dominating the business world in recent years. Customer relationship management is a new competitive weapon for organizations for serving internal and external customers. Today's organizations are focusing on conquering the minds of customers, to make them satisfied and loyal with the help of sophisticated, well-organized CRM efforts. This paper is to explore the CRM agenda in organizational interfaces and its effectiveness with regards to customer satisfaction and customer loyalty. The related literature demonstrates that there is a significant association among effective CRM, customer satisfaction and customer loyalty.
\end{abstract}

Keywords: Customer Relationship Management (CRM), Customer Satisfaction, Customer Loyalty JEL classification: M31

\section{Introduction}

The concept of Customer Relationship Management (CRM) has been a widely cited topic of marketing scholars and marketers over last 35 years. CRM is derived from the word "contract management" which emerged in the 1980s about preserving customer details for further contact with customers. Customer Relationship Management is an organizational strategy to develop mutually profitable long-term relationships with the customer. It helps the company to collect and preserve customer details through continuous survey of information about products and services offered to the customer (Bergeron, 2002). In this way, companies can customize the suitable product and service preferred by the customer (Sun, 2009). Customer relationship management systems are becoming popular across most sectors and have emerged as a chief business strategy in today's competitive environment. CRM has been widely accepted and practiced as the most effective marketing technique involving human and technical dimensions. It involves an all-round customer centricity and commitment of the entire organization. Effective CRM has become a critical challenge in business competition and marketing and economic advancement of a country.

Customer relationship management ensures the relationships with customers to increase the organization's market share by integrating technology, procedures and people. CRM is to maintain the customers and increase their satisfaction and the organization's profit. Customer satisfaction is the main element in a successful CRM implementation for retaining customers (Long, Khalafinezhad, Ismail and Rasid, 2013). In modern business, if any competitor wants to gain additional market share, with no doubt he has to handle customers in an effective and efficient way.

Every organization seeks to maintain and use critical information regarding the needs, expectations and choices of customers to make them satisfied and loyal. Customer 
loyalty is such a kind of valuable situation where an organization ultimately gains profitability. But achieving customer loyalty is not an easy task. To build positive relations with a customer, to fulfill a customer's needs and want, to manage customer expectations are the main goals. An organization can attempt to achieve these goals using an effective CRM. Customer relationship management undoubtedly influences customer loyalty for the organization. Now, it is theoretically developed and empirically verified that CRM is positively related to customer satisfaction and loyalty. On the basis of these facts, researchers are motivated to investigate the relationship among customer relationship management, customer loyalty and satisfaction.

This theoretical research is based on a threefold objective, which is related to the customer satisfaction and loyalty relationship with CRM. In order to achieve the objectives of this study, a comprehensive literature review has been done in the field of customer relationship management. Therefore, the objectives of the study are:

To review the CRM agenda in contemporary organizations.

To review the CRM effects on consumer satisfaction.

To review the CRM effects on customer loyalty.

\section{CRM Agenda in a Temporary Organization}

\subsection{CRM}

CRM is a technique that can help build long-term relationships with the customers and increase profits through efficient management systems and the application of customer-focused strategies. Customer relationship management is a customer oriented marketing effort which is responsible for accumulating and managing customer details in order to serve the customers in the present and future. CRM is a strategic marketing process whose purpose is to predict, understand and manage the demand of customers. Customer Relationship Management is the establishment, development, maintenance and optimization of long-term mutually valuable relationships. It is a set of business practices to identify, verify, acquire, develop and maintain sustainable profitability and customer loyalty through providing appropriate product and services, in due time (Galbreath and Rogers, 1999). Customer Relationship Management is a comprehensive strategy and process of acquiring, retaining and partnering with customers to create superior values for the company and the customer (Parvatiyar and Sheth, 2001). It is a method of understanding the customer behavior through intense communication with him/her to improve the performance, which is represented in attracting the customer, keeping him/her and increasing his/her loyalty and profitability (Swift, 2000). A company uses CRM in the field of research methodology, technology and e-commerce in order to manage customer relationships (Foss and Stone, 2001). This definition for CRM regards it as the ability to use technology in the domain of dealing with customers. CRM is the activity which is interested in the main customers of the organization, in the efficiency of an organization and in the customer knowledge management, with the aim of enhancing the effectiveness of organizational decisions related to customers, leading, therefore, to the improvement of marketing performance in particular and organizational performance in general (Zablah, 2004). 


\subsection{CRM Objectives}

It is considered that CRM is not a product or service; it is an overall business strategy that enables companies to effectively manage relationships with their customers. It provides an integrated view of a company's customers to everyone in the organization. The reasons for CRM coming into existence are the changes and developments in the marketing environment and technology. The goal of an efficient Customer Relationship Management (CRM) strategy is to develop, keep and retain profitable customers. Therefore, the objectives of CRM are presented as:

\section{Improve the Communication Process with Customers}

CRM itself is a learning process in which information is regularly updated and communicated with customers so that customer demand can be analyzed and appropriate response to the customer can be carried out (Alehojat, Chirani and Delafrooz, 2013). It facilitates organizations to maintain a stable market demand of the product offered by them.

\section{To Identify the Key Elements of CRM}

CRM is important for an organization for the sustainable growth of its profitability. Identification of CRM determinants relates to the nature of the organization. CSR determinants can be used to promote service quality for making customer satisfied. The elements are the power indicators that directly influence CRM's overall studies. People, culture, relationship management process, knowledge management, IT, organization, customer and value are the valuable elements of CRM (see Fig. 1). These elements also affect the factors of CRM (Shamsuddoha, Tasnuba and Alamgir, 2011).

\section{Figure 1 | Key elements of CRM}

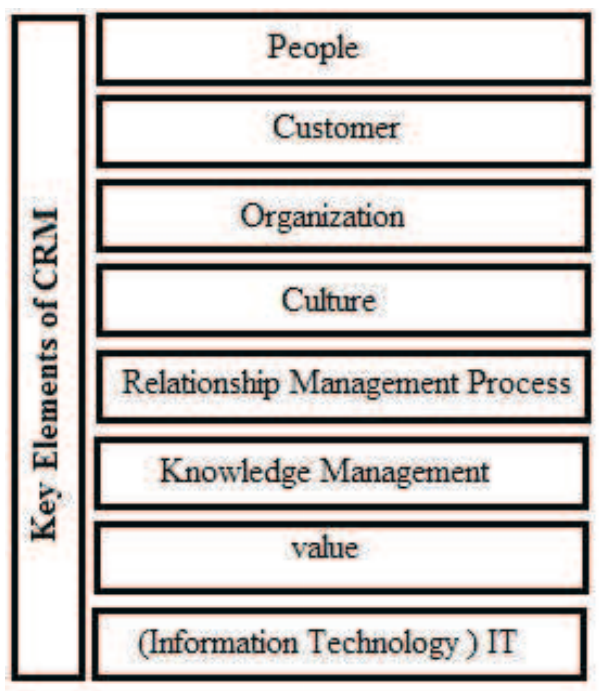

Source: Authors. 


\section{To Identify the Factors Related to CRM Effectiveness}

According to Karakostas, Kardaras and Papathanassiou (2005), the factors that influence the CRM implementation are new customer attraction, consumer buying behavior, competitive advantage, customer satisfaction, customer retention, acquisition, long-term relationship, knowledge management, web enabled customer service, customer value, etc. Tekin (2013) argues that IT, long-term relationship, higher profitability and significant investment in technology are the main influencing factors of CRM. CRM factors relate to IT, human resources, organizational structures, and reward systems (Rigby, Reichheld and Schefter, 2002). Multiple CRM factors approaches by different researchers includes: reliability, customization, customer attraction, customer retention, information technology (IT), responsiveness, commitment, and customer orientation.

\subsection{Benefits of CRM}

CRM is an essential way to understand what motivates customers. Customer relationships are becoming even more important as market conditions get more adverse. Due to increasing competition in the marketplace, demand patterns of customers are changing, as well as the life cycle of products and services. CRM can be used to investigate what the customers expect, what channel of distribution they prefer, and what attributes should be incorporated in product and services. Understanding the customer through CRM allows organizations to offer the desired service to the customer. CRM benefits to customers may include:

\section{CRM Increases Customer Retention and Loyalty}

Basically, a customer is loyal when he is committed to repurchasing a preferred service or product even when there are marketing efforts and situational influences having the potential to cause switching behavior (Oliver, 1999). It is suggested to the companies to invest in relationship building and customer intimacy with loyal customers as it will in turn lead to stronger loyalty (Oly Ndubisi, 2004). The customers who regularly purchase a company's product over a long period of time tend to generate more revenues and are relatively cheaper to serve than other customers (Reichheld and Aspinall, 1993). Higher customer profitability is ensured by CRM. CRM creates more value for the customer, so undoubtedly CRM builds profitable customer relationships.

\section{Customization of Products and Services}

The main concentration of CRM is on two major areas: To create a closer and deeper relationship with customers and to increase organizational capability to coordinate its behavior with individual customers based on customer needs, or what the organization knows about his/her requirements and interests. This is because existing customers are always more profitable than new ones, and selling more products to existing customers is less costly. Coordinating the products and services with consumer needs and expectations results in attracting more customers. Consequently, attracting new customers is much more costly. Indeed, the main goal of CRM is to maximize the value of customer life cycles for the organization (Payne and Frow, 2004). The recent marketing procedures are 
approaching towards providing a unique service; this is why acquiring large volumes of customer information and details has become a pivotal requirement. In order to predict the probability of repeat purchase, or buying additional products and individual marketing programs, the organization has to collect the customer's information based on their interactions with the organization (Peppard, 2000).

\section{CRM Maintains Lower Process and Higher Quality of Products and Services}

The activities of CRM directly influence products and services and also internal processing systems. CRM can help reduce operational costs by effective relationship with customers and minimizes the size of overall processes. On the other hand, an effective CRM can help increase qualitative products and services by customer interactions (see Fig. 2).

\section{Figure 2 | CRM effects of Product and Process}

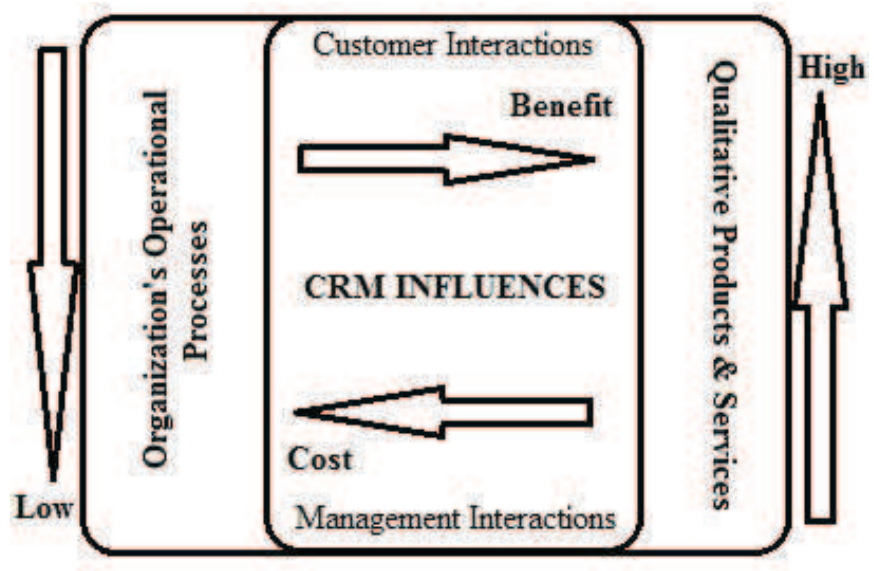

Source: Authors.

\section{Meet Customer Expectations}

The key to customer loyalty is customer satisfaction, which largely depends on the service quality offered by service providing firms (Rahman, 2014). Service quality and customer expectations have been identified as key elements of the service-profit chain (Heskett, Sasser, and Schlesinger, 1997). Better service quality results in satisfied customers, which in turn leads to strong customer loyalty. It can be stated that customers, when satisfied with the services they have experienced, are more likely to establish loyalty (Taylor, Sharland, Cronin, and Bullard, 1993), resulting in repeat purchases (Fornell, 1992) and favorable word-of-mouth (Halstead and Page, 1992). Customer service quality is a significant source of distinctive competence and often considered a key success factor in sustaining competitive advantage in service industries (Palmer, 2001). Therefore, a firm can be able to meet customer expectations through effective CRM. 


\section{Improvement in Customer Satisfaction and Loyalty}

Feliks and Panjaitan (2012) suggest that companies implementing CRM in a proper way will enjoy increased customer satisfaction. Kusnadi's research results (2008) also showed that the CRM application helps companies to gain customer knowledge that helps them improve customer satisfaction. This is also supported by the study of Wetsch and Lyle (2006) who found that the potential impacts caused by the customer involvement in the CRM implementation are trust, satisfaction and customer loyalty. Munandar and Dadang (2011) suggest that CRM has positive and significant effects on customer loyalty, and that changes in the company's customer loyalty are directly related to changes in the implementation of CRM. This means that to increase customer loyalty, CRM needs to be implemented first. A better CRM implementation links to customer satisfaction and loyalty. This indicates that customer loyalty needs more companies' attention, because loyalty will ultimately affect the performance of the company.

\subsection{Factors Affecting CRM}

- Reliability - Reliability is one of the most common factors of CRM. The activity of CRM is to identify reliable customers and to communicate with them. On the other hand, CRM reliability largely depends on the reliability of IT systems in which customer relations are managed. Customer relationship management activities always try to fill a customer's expectations and provide better customer service, which isn't always possible without reliability. Reliability is defined as performing the task dependably and accurately (Parasuraman, Zeithaml and Berry, 2004). This is achieved through keeping promises to do something, providing the right service, consistency of performance and dependability, service is performed at the right time, the company keeps accurate billing and keeps records correctly, and transactions and records are error-free. Reliability also consists of accurate order fulfillment, accuracy records, accurate quotes, accurate billing, accurate calculation of commissions and keeping any promises regarding services.

- Customization - The core of customization is based on acceptable delivery times and prices, and providing customers with personalized products. CRM offers the customization of products and services, so that the existing and potential needs of customers are met. CRM provides a variety of useful information to the customers. CRM allows mutual connectivity between customer and organization in order to allow customization in products and services delivered.

- Customer Attraction - Valued customers are always providing good feedback. Customer attraction acts as a driver of customer commitment. CRM is a systematic marketing effort of understanding customers, especially what they expect, to what extent, and what should be incorporated into products and services.

- Customer Retention - Customer retention is one of the most important indicators of customer satisfaction. The more satisfied customers are, the greater is their retention. Customer retention is becoming an important managerial issue, especially in the context of a saturated market, when the growth of the number of new customers is declining. It has been acknowledged as a key objective of relationship marketing 
primarily because of its potential in delivering superior relationship economies, i.e. it costs less to retain than to acquire new customers.

- Information Technology (IT) - The role of IT is to help redesign CRM processes, to facilitate changes to work practices, and to establish innovative methods to link a company with customers, suppliers and internal stakeholders. CRM applications take full advantage of technology innovations with their ability to collect and analyze data on customer patterns, interpret customer behavior, develop predictive models, respond with timely and effective customized communications and deliver product and service value to individual customers. (Chen and Popovich, 2003). By using IT, CRM can optimize interactions with customers based on historical data.

- Responsiveness - Responsiveness is the determinant that defines the willingness to help customers and to provide prompt service. CRM has been always responsible to provide information to the customer. Service propositions like "what can I do for you" clearly underline the importance of customers. It is also involved in understanding the needs and wants of the customers, convenient operating hours, individual attention given by the staff, attention to problems and customers safety (Arun Kumar, Tamilmani, Mahalingam and Mani, 2010).

- Customer Orientation - Customer relationship management is a customer oriented, organized managerial effort to ensure perceived value of customers in order to make them satisfied and loyal. Customer relationship management cares about suggestions and preferences given by customers. CRM allows customers to share the post consumption experience, therefore, management can effectively take care of customer inquiries.

- Commitment - Commitment is an essential prerequisite for ensuring the efficient delivery of customer value having an approval to the CRM project. CRM should set the stage of leadership and commitment throughout the CRM implementation. Management support and involvement reinforce the commitment as a key success factor of CRM implementation. CRM effectiveness without a commitment is like throwing money into a black hole. The effectiveness of CRM commitment is determined by the extent to which customers are satisfied and loyal.

Figure 3 | CRM Factors

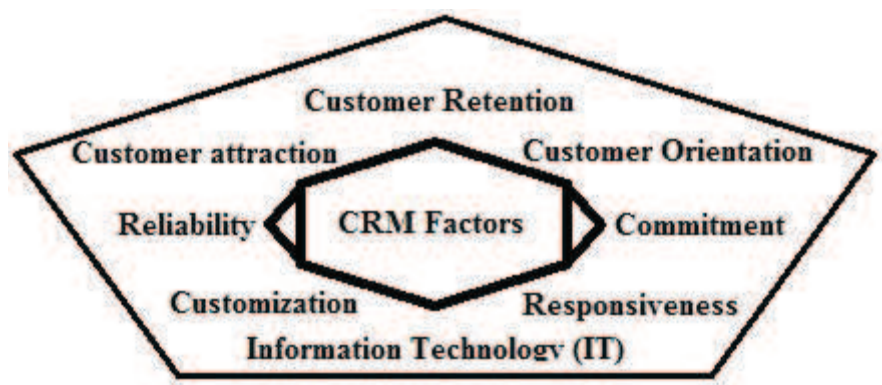

Source: Authors. 


\section{CRM Effects on Customer Satisfaction}

Customer satisfaction is the extent to which customers are satisfied with their purchased goods and services (Boone and Kurtz, 2013). Customer satisfaction is a statement to the buyer about the appropriateness of the reward, received in exchange for the service experienced. Every firm tries to fulfill customers' needs, desires, wants, aims and expectations. Therefore, production and marketing department collaboratively produce economic utility for customers. Customer satisfaction is generally understood as the pleasure of using product and service. Customer satisfaction is the voice of customer that will differ from person to person. It is an appraisal of how products and services of a company meet up or exceed customer anticipation.

Jeong and Lee (2010) defined customer satisfaction as:

- Customers' satisfaction is an emotional (sentimental) reaction or a manner of interactive recognition and perception.

- Customers' satisfaction is a response to the specific concentration on the expectations of production and the experience of using services and consumption.

- Customers' satisfaction is a judgmental reflection of customers about a product or service during the time period of its usefulness.

- Customers' satisfaction is a summary of the psychological manner in which a composite of customers' feeling about the unexplained expectations and his/her previous consumption experiences are encompassed.

Figure 4 | Dimensions of Customer Satisfaction

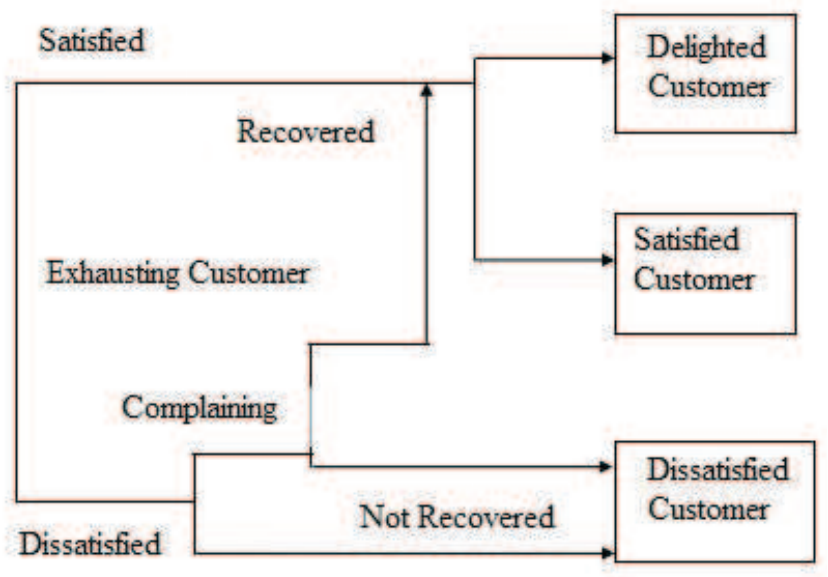

Source: Hays and Hill (1999).

A satisfied customer always connects with a service provider. CRM is a formation that ensures customer satisfaction. CRM is a systematic process of building long-term relationships with its customer by providing optimum satisfaction. The organization actively takes the necessary steps in order to promote satisfaction. Maintaining the desired level of customer satisfaction requires a proactive corporate responsiveness in accessing, building 
and retaining satisfied customers for sustainable competitive advantages in market place (Rahman, Redwanuzzaman, Masud-Ul-Hasan and Rahman, 2014). CRM effects have a positive impact on customer satisfaction. If an organization has a good CRM strategy, then customer satisfaction will automatically be increased; on the other hand, the absence of a good CRM strategy will result in customer dissatisfaction. CRM factors also affect customer satisfaction. Sound, reliable, customized information technologies etc., positively affect customer satisfaction.

By using modern communication media, CRM can easily communicate with customers while fulfilling their expectations. The fulfillment of customer expectations will help enhance customer satisfaction. A highly satisfied customer:

- continues his shopping for a long time,

- buys more as long as the firm produces new products and the existing products are improved,

- speaks of the firm and its products with praise,

- keeps indifferent to the trademarks that are in competition with the products of the firm and does not place the emphasis on price,

- and offers the firm suggestions and ideas about products and services.

Nowadays, most organizations have adapted customer-centered philosophy to fulfill the customer needs and to enhance perceived values of customer. Hence, adopting customer-centric strategies aimed at maintaining and enhancing relationships with existing customers is important for survival (Krishnamoorthy and Srinivasan, 2013). Highly satisfied customers of a firm are likely to purchase more frequently, in greater volume and buy other goods and services offered by the same service provider. Many companies focus on finding new customers instead of retaining and satisfying the existing customer base. However, since competition among companies is tough, the retention of customers has become more important than the acquisition of new customers. In recent years, companies have realized that a critical success factor is not a single transaction, but the creation of a long-term relationship by the method of CRM (Ampoful, 2012).

\section{CRM Effects on Customer Loyalty}

Customer loyalty can be seen as a customer commitment to deal with a particular firm, and buy their products and services. A loyal customer encourages others to do business with the firm. Loyal customers are also considered to be the most important assets of a company and it is thus essential to keep loyal customers who will contribute long-term profit to the organization. In a business context, loyalty is a psychological awareness process or the observable reaction of a consumer, where intentional and factual retention or intensification of the relationship is based on specific reasons (Keaveney, 1995). Loyalty requires a positive attitude of the consumer towards a company and its services; retention, on the other side, can also exist with a negative attitude towards a company (Bruhn, 2009).

Customer loyalty is related to a service provider's ability to maintain its customers' loyalty and persuade them to recommend its services to potential customers (Zeithaml, Berry and Parasuraman, 1996). Six indicators were used to measure customer loyalty: 
share information, say positive things, recommends a friend, continue purchasing, purchase additional service and test new service (Brodie, Roberts and Varki, 2003).

Customer loyalty can be achieved through a successful CRM implementation. An effective customer relationship management is positively related to the loyalty of customers. CRM helps organizations to build long-term relationships with their customer.

Figure 5 | Dimensions of Customer Loyalty

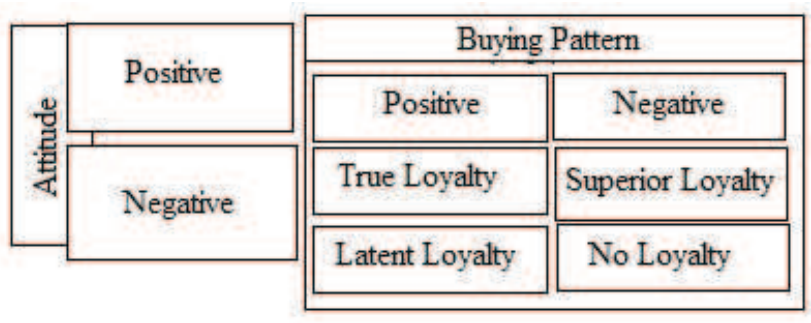

Source: Dick and Basu (1994).

Figure 6 | CRM Effects on Customer Satisfaction and Customer Loyalty

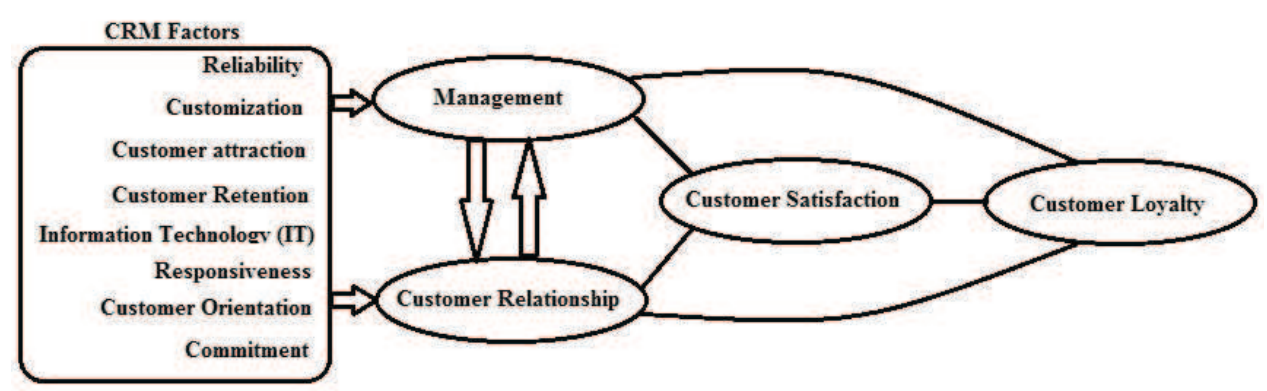

Source: Authors.

Nowadays, customer retention is becoming very flexible. Customers switch to products and services offered by other organizations when they are dissatisfied. Organizations should offer high-quality products and services with a competitive price in order to promote customer loyalty. Customer relationship management can be a useful mechanism to render the customers loyal. The level of loyalty can be measured by observing the frequency of visits and buying behavior of customers. Today's customers are aware of the power they have on the market and that every activity is realized for them. It is now easier to find products and services. Before choosing a given trademark, consumers look at the price, newness, accessibility of the product and the additional services offered. As the alternatives increased, consumers' loyalty to the products and services decreased. Today, firms have entered into an effort to present at a lower cost than their rivals the products and services that can meet the customer wishes and expectations fully, so that they can render customers more loyal. CRM provides the exact and right time information about products and services quality, feature, core value etc (Koçoğlu and Kirmaci, 2012). 
On the basis of a review of the related literature, a circulation process of CRM and its effect on customer satisfaction and loyalty has been built.

\section{Conclusion and Managerial Implications}

The goal of this paper was to theoretically access the impact of customer relationship management on customer satisfaction and customer loyalty based on the review of existing literature. Various CRM factors have been identified that are closely linked with customer satisfaction and loyalty. The study demonstrates that CRM has a direct and positive relationship with customer satisfaction and customer loyalty. Customer loyalty also has a positive relationship to customer satisfaction. CRM factors are supposed to have a significant impact on customer satisfaction and loyalty. The study finds the components of CRM that constitute a CRM process, and interconnected links among customer relationship management, customer satisfaction and customer loyalty. The authors present the benefits that can be achieved through an effective CRM implementation.

The quality-of-service positively affects customer satisfaction; implementing good CRM will increase customer satisfaction.

The quality-of-service positively affects customer loyalty; implementing good CRM will increase customer loyalty.

Customer satisfaction is positively related with customer loyalty. When customers become satisfied they are likely to remain repeat customers.

This study also has several managerial implications. For firms evaluating CRM applications, it is important to understand the conditions under which deployment of those applications contributes to improved customer loyalty and customer satisfaction. Our results, which show the importance of customer loyalty and customer satisfaction integration in realizing the benefits from CRM applications, could be useful to managers who are currently evaluating or implementing CRM applications. Firms with greater interaction with customers are more likely to benefit from CRM applications in terms of customer loyalty and customer satisfaction. The results imply that firms need to be willing to share their customer-related information with supply chain partners to benefit from the implementation of CRM applications.

The importance of customer knowledge as a mediator of customer satisfaction suggests that in addition to implementing CRM, managers should also ensure that customer knowledge is disseminated across customer touch points in order to benefit in terms of customer satisfaction. An implication of this finding is that managers need to institute measurement systems to capture the gains in customer knowledge following the implementation of CRM applications because gains in customer loyalty are a precursor to gains in customer satisfaction.

Given the favorable effects of CRM practices on organizational performance, the logical question arises: at an individual level, how can companies, employees, especially people/organization who interact with customers daily, increase their contributions to successful CRM?

Training programs with CRM are crucial for employees, especially salespeople who regularly interact with customers. In particular, training programs are essential in conveying the importance and nature of a CRM orientation to salespeople so that they acquire the requisite relationship development skills and sensitivity to changing customer needs. Such training programs are crucial because customer expectations are changeable. 
Management should attend to the communication of CRM strategies and objectives of all employees. CRM responsibilities must be clearly defined, assigned, and understood via unequivocal communication. Therefore, management needs accurate and timely information to build effective and efficient customer relationship management.

\section{References}

Alehojat, S., Chirani, E., and Delafrooz, N. (2013). Conceptual Framework of CRM Process in Banking System. Arabian Journal of Business and Management Review, 1 (2).

Ampoful, A. (2012). The Effect of Customer Relationship Management (CRM) on the Profitability of Financial Institutions-A Case Study of Barclays Bank Limited, Takoradi Branches (Doctoral dissertation). Institute of Distance Learning, KNUST.

Arun Kumar, S., Tamilmani, B., Mahalingam, S., and Mani, V. K. (2010). Influence of service quality on attitudinal loyalty in private retail banking: An empirical study. The IUP Journal of Management Research, 9 (4): 21-38.

Bergeron, B. (2004). Essentials of CRM: A guide to customer relationship management (Vol. 14). New York: John Wiley and Sons.

Boone, L., and Kurtz, D. (2013). Contemporary marketing. Cengage Learning.

Bruhn, M. (2009). Relationship Marketing. Vahlen Munchen.

Chen, I. J., and Popovich, K. (2003). Understanding customer relationship management (CRM) People, process and technology. Business process management journal, 9 (5): 672-688.

Dick, A. S., and Basu, K. (1994). Customer loyalty: toward an integrated conceptual framework. Journal of the academy of marketing science, 22 (2): 99-113.

Feliks, Anggia, B.K.P, and Hotman Panjaitan, (2012).The Effects of Customer Relationship Management and Service Quality towards Customer Loyalty through Customer Satisfaction. The International Conference on Sustainable Development, 159-175.

Fornell, C. (1992). A National Customer Satisfaction Barometer: the Swedish Experience. Journal of Marketing, 56 (1): 6-21.

Galbreath, J., and Rogers, T. (1999). Customer relationship leadership: a leadership and motivation model for the twenty-first century business. The TQM magazine, 11 (3): 161-171.

Halstead, D., and Page Jr., T.J. (1992). The Effects of Satisfaction and Complaining Behavior on Consumers Repurchase Behavior. Journal of Satisfaction, Dissatisfaction and Complaining Behavior, 5: 1-11.

Hays, J. M., and Hill, A. V. (1999). The market share impact of service failures. Production and Operations Management, 8 (3): 208-220.

Heskett, J.L., Sasser, W. E., and Schlesinger, L.A. (1997). The Service Profit Chain: How Leading Companies Link Profit and Growth to Loyalty, Satisfaction and Value. Free Press: New York.

Jeong, Y., and Lee, Y. (2010). A study on the customer satisfaction and customer loyalty of furniture purchaser in on-line shop. Asian Journal on Quality, 11 (2): 146-156.

Karakostas, B., Kardaras, D., and Papathanassiou, E. (2005). The state of CRM adoption by the financial services in the UK: An empirical investigation. Information and Management, 42: 853-863.

Keaveney, S. M. (1995). Customer switching behavior in service industries: An exploratory study. The Journal of Marketing, 71-82. 
Koçoğlu, D., and Kirmaci, S. (2012), Customer Relationship Management and Customer Loyalty; A Survey in the Sector of Banking. International Journal of Business and Social Science, 3 (3): 282-291.

Krishnamoorthy, V., and Srinivasan, R. (2013). Impact of Customer Relationship Management on Loyalty in Indian Banking Sector- An Empirical Study. International Monthly Refereed Journal of Research In Management and Technology, 2, 151-161.

Kusnadi, A. M., (2008). Customer Relationship Management And Service Quality Analysis Toward Customer Value Through Customer Satisfaction On Government Bank At Surabaya, Disertasi.Postgraduate UNTAG Surabaya.

Long, C. S., Khalafinezhad, R., Ismail, W. K. W., and Rasid, S. Z. A. (2013). Impact of CRM factors on customer satisfaction and loyalty. Asian Social Science, 9 (10): 247-253.

Munandar, Dadang, (2011). The Effect of Customer Relationship Management toward Customer Loyalty Business at PT. Frisian Flag Bandung, Majalah Ilmiah Unikom, Bandung.

Oliver R L. (1999). Whence Consumer Loyalty? Journal of Marketing, 63, 33-44.

Oly Ndubisi, N. (2004). Understanding the salience of cultural dimensions on relationship marketing, its underpinnings and aftermaths. Cross Cultural Management: An International Journal, 11 (3): 70-89.

Palmer, A. (2001). Principles of Service Marketing. McGraw-Hill: New York, 227.

Parasuraman, A., Zeithaml, V. A., and Berry, L. (2004). SERVQUAL: a multiple-item scale for measuring consumer perceptions of service quality. Retailing: Crit Concepts Bk2, 64 (1): 140.

Parvatiyar, A., and Sheth, J. N. (2001). Customer relationship management: Emerging practice, process, and discipline. Journal of Economic and Social research, 3 (2): 1-34.

Payne, A., and Frow, P. (2004). The role of multichannel integration in customer relationship management. Industrial marketing management, 33(6), 527-538.

Peppard, J. (2000). Customer Relationship Management (CRM) in Financial Services. European Management Journal, 18 (3): 312-327

Rahman, M. H. (2014). Factors affecting customer satisfaction in mobile telecommunication industry in Bangladesh. Business, Management and Education, 12 (1): 74-93.

Rahman, M. H., Redwanuzzaman, M., Masud-Ul-Hasan, M., and Rahman, M. A. (2014). Factors Affecting Customer Satisfaction on Grameenphone Users in Bangladesh. Global Journal of Management and Business Research, 14 (3): 57-66.

Reichheld, F.F. and Aspinall, K. (1993), Building high-loyalty business systems, Journal of Retail Banking, 15: 21-9.

Reinartz, W., Krafft, M., and Hoyer, W. D. (2004).The Customer Relationship Management Process: Its Measurement and Impact on Performance. Journal of Marketing Research, 293-305.

Rigby, D.K., Reichheld, F.F., and Schefter, P. (2002). Avoid the four perils of CRM. Harvard Business Review, 80, 101-109

Roberts, K., Varki, S., and Brodie, R. (2003). Measuring the quality of relationships in consumer services: an empirical study. European Journal of marketing, 37 (1/2): 169-196.

Shamsuddoha, M., Tasnuba and Alamgir, M. (2011). Determinants of Customer Relationship Management (CRM): A Conceptual Analysis. Fascicle of the Faculty of Economics and Public Administration, 10 (1): 95-101.

Stone, M., and Foss, B. (2001). Successful customer relationship marketing. Kogan, London, U-nited Kingdom, Chapter Defining CRM and Assessing its Quality, 3-20. 
Sun, Z. (2009). Customer Relationship Management and Privacy. International Business Research, 2 (1): 112-116.

Swift, R. S. (2001). Accelerating customer relationships: Using CRM and relationship technologies. Prentice Hall Professional.

Taylor, S.A., Sharland, A., Cronin, A.A. Jr., and Bullard, W. (1993). Recreational quality in the international setting. International Journal of Service Industries Management, 4 (4): 68-88.

Tekin, M. (2013). Critical Success Factors for a Customer Relationship Management Strategy. Mediterranean Journal of Social Sciences, 4 (10): 753.

Wetsch, Lyle R., (2006). Trusted Third Parties: Evaluating Their Effect on Online Consumer Buying Intentions. Working Paper, School of Business Queen's University.

Zablah, A. R., Bellenger, D. N., and Johnston, W. J. (2004). An evaluation of divergent perspectives on customer relationship management: Towards a common understanding of an emerging phenomenon. Industrial marketing management, 33 (6): 475-489.

Zeithaml, V. A., Berry, L. L., and Parasuraman, A. (1996). The behavioral consequences of service quality. The Journal of Marketing, 31-46.

\section{Authors}

\section{S. M. Kamrul Islam Shaon}

MBA Research Fellow

Department of Business Administration

Pabna University of Science and Technology

shaonbba.pust@gmail.com

\section{Md. Hasebur Rahman}

Assistant Professor

Department of Business Administration

Pabna University of Science and Technology

Pabna-6600, Bangladesh

hasebur7208@yahoo.com 